\title{
Analisis Penerimaan Sistem Informasi Rumah Sakit Padma Lalita Menggunakan TAM
}

\author{
Acceptance Analysis of Padma Lalita Hospital Information System \\ Using TAM
}

\author{
Yusuf Wahyu Setiya Putra*1, Kusrini ${ }^{2}$, Ferry Wahyu Wibowo ${ }^{3}$ \\ 1,2,3 Magister Teknik Informatika Universitas AMIKOM Yogyakarta \\ E-mail: *1yusufputra21@gmail.com, ${ }^{2}$ kusrini@amikom.ac.id, ${ }^{3}$ ferry.w@amikom.ac.id
}

\begin{abstract}
Abstrak
Tujuan dari penelitian ini adalah untuk menganalisis penerimaan user pada sistem informasi rumah sakit dengan menggunakan variabel Kegunaan yang Dirasakan (Perceived Usefullness), kemudahan yang dirasakan (Percieved Ease of Use) dan variabel sikap pengguna (Atittute toward Using) yang ada pada TAM (Technology Acceptance Model). Sampel pada penelitian ini berjumlah 66 responden. Data diperoleh menggunakan kuesioner yang telah diuji validitas dan reliabilitasnya, kemudian dianalisis dengan teknik regresi linier berganda. Hasil analisis persamaan regresi ke-1 menunjukkan variabel Perceived Usefullness (XI) memiliki pengaruh signifikan terhadap variabel Attitute toward Using $(Y)$ dengan thitung sebesar 6,551 dengan signifikansi $p=0,000(<0,05)$. Variabel Percieved Ease of Use (X2) berpengaruh signifikan terhadap variabel Attitute toward Using (Y) dengan thitung 1,988 dengan signifikan $p=0,011(<0,05)$. Hasil analisis persamaan regresi ke-2 menunjukkan bahwa variabel X1 dan $X 2$ secara bersama-sama berpengaruh signifikan terhadap Attitute toward Using (Y) karena nilai statistik $F$ Hitung $=59,712$ dengan signifikansi $p=0,000(<0,05)$.
\end{abstract}

Kata Kunci - Sistem informasi, Perceived Usefulness, Perceived Ease of Use, Attitude Toward Using, TAM

\section{Abstract}

The purpose of this study is to analyze user acceptance in hospital information systems using Perceived Usefulness, Perceived Ease of Use, and Atittute toward Using variables in TAM (Technology Acceptance). Model). The sample in this study amounted to 66 respondents. Data obtained using questionnaires that have been tested for validity and reliability, then analyzed by multiple linear regression techniques. The results of the analysis of the 1st regression equation show that the Perceived Usefulness variable (XI) has a significant influence on the Attitute toward Using $(Y)$ variable with $t$ count of 6.551 with significance $p=0.000(<0.05)$. The variable Percieved Ease of Use (X2) has a significant effect on the Attitute toward Using (Y) variable with $t$ count 1.988 with a significant $p=0.011(<0.05)$. The results of the analysis of the second regression equation show that variables $X 1$ and $X 2$ together have a significant effect on Attitute toward Using $(Y)$ because the statistical value $F$ count $=59.712$ with significance $p=0.000$ $(<0.05)$.

Keywords - Information System, Perceived Usefulness, Perceived Ease of Use, Attitude Toward Using, TAM 


\section{PENDAHULUAN}

Penerapan sistem yang baru pada RS Padma Lalita ini merupakan sistem baru yang terkomputerisasi dan berbeda dengan sistem terdahulu yang belum terkomputerisasi. Maka dari itu, penggunaan sistem yang baru perlu dilakukan analisis apakah sistem yang baru tersebut dapat digunakan dengan baik dan bermanfaat bagi penggunanya.

Dengan penerapan sistem yang baru ini khususnya sistem informasi rumah sakit, maka akan menghasilkan reaksi pada penggunanya. Reaksinya bisa berupa penerimaan pada teknologi baru tersebut atau bahkan akan menolaknya. Banyak peneliti mengakui bahwa kepuasan pemakai teknologi informasi merupakan indikator penting dalam menentukan keberhasilan dalam mendesain dan mengimplementasikan teknologi informasi. Menurut Davis tingkat dimana seseorang meyakini bahwa penggunaan teknologi informasi merupakan hal yang mudah dan tidak memerlukan usaha keras dari pemakainya serta tingkat keyakinan seseorang bahwa penggunaan teknologi informasi tertentu akan meningkatkan kinerjanya. Davis juga menjelaskan bahwa tingkat penggunaan sebuah teknologi pada seseorang dapat diprediksi dari sikap perhatiannya terhadap teknologi tersebut, misalnya keinginan untuk menambah fitur pendukung dan motivasi untuk tetap menggunakannya [1].

Penerimaan dan penggunaan konsumen Instagram mengatakan bahwa umumnya penerimaan dan penggunaan Teknologi informasi telah menjadi salah satu yang paling banyak diteliti yaitu dengan menggunakan model Technology Acceptance Model (TAM) dan Unified Theory of Acceptance and Use Technology (UTAUT) yang sama-sama memiliki hampir 40.000 kutipan menurut Google Scolar [2]. Sebelumnya telah banyak yang melakukan penelitian yang membandingkan kedua model tersebut, diantaranya Megawati yang meneliti tentang analisis perbandingan Metode TAM dan UTAUT dalam mengevaluasi penerimaan pengguna Sistem Informasi Manajemen Rumah Sakit (SIMRS) Rumah Sakit Jiwa Tampan Provinsi Riau, dengan hasil penelitiannya menunjukkan bahwa perbandingan metode TAM dan UTAUT didapatkan hasil Metode TAM lebih menjelaskan penerimaan pengguna SIMRS dengan konstruk kemudahan atau yang berpengaruh terhadap konstruk kegunaan sedangkan metode UTAUT menjelaskan penerimaan pengguna SIMRS dengan konstruk ekspektasi usaha berpengaruh terhadap ekspektasi kinerja [3].

Minat pengguna tehadap teknologi web check-in yang ada di bandara Kalimantan Barat. Model TAM digunakan dengan menambahkan variabel trust dan risk. Data dianalisis dengan structural equation modeling. Hasil menunjukkan bahwa model fit dengan chi 2 yang tidak signifikan dan indikator goodness of fit yang baik [4]. Penerapan aplikasi Sistem Akuntansi Persediaan yang diterapkan oleh Distrik Navigasi Kelas III Pontianak sudah dapat diterima dengan baik oleh karyawan yang menerapkanya baik secara individual maupun secara berkelompok dengan menggunakan analisis metode TAM. Pelatihan-pelatihan yang diberikan selama ini ternyata tidak sia-sia dan memberikan hasil yang positif. [5].

Penelitian yang membandingkan Metode HOT FIT dan TAM dalam mengevaluasi penerapan Sistem Informasi Manajemen Kepegawaian (SIMPEG) di pengadilan tata usaha negara Pekanbaru dengan hasil kesimpulan bahwa dari perbandingan metode HOT FIT dan TAM, didapatkan hasil bahwa hasil pengolahan data metode TAM adalah metode terbaik untuk mengevaluasi penerapan SIMPEG di PTUN Pekanbaru. Metode TAM lebih menjelaskan keberhasilan penerapan SIMPEG [6]. Banyak model yang diusulkan untuk menjelaskan penerimaan teknologi informasi namun hanya TAM yang dapat dianggap sebagai model yang paling terbaik [7].

Berdasarkan uraian latar belakang dan beberapa penelitian diatas yang menjelaskan berbagai metode yang dapat digunakan untuk menetukan tingkat penerimaan user terhadapat sistem, maka peneliti akan melakukan analisis penerimaan sistem informasi rumah sakit RS Padma Lalita Magelang menggunakan model TAM untuk mengetahui tingkat penerimaan sistem informasi rumah sakit, memberi saran dan rekomendasi. Model TAM dipilih karena dari beberapa penelitian diatas menegaskan bahwa untuk mengukur tingkat penerimaan SIMRS yang paling 
baik adalah menggunakan model TAM. Kemudian hasil dari penelitian ini dapat digunakan untuk meningkatkan dan memperbaiki sistem informasi yang sudah ada.

\section{METODE PENELITIAN}

Penelitian ini menggunakan model Technology Acceptance Model (TAM). Rancangan penelitian yang digunakan yaitu kuantitatif dengan riset survei. Subjek penelitian ini adalah pengunjung website Sistem Informasi RS Padma Lalita yang telah menggunakan sistem informasi berbasis website tersebut. Instrumen penelitian yaitu kuesioner yang berisi pertanyaan dengan menggunakan skala likert 1- 5. Cara pengumpulan data dengan membagikan kuesioner kepada pengguna aplikasi. Analisis data dilakukan dengan bantuan software SPSS yang diolah menggunakan teknik analisis deskriptif dan teknik regresi linier berganda [8].

\subsection{Metode Pengumpulan Data}

Metode pengumpulan data pada penelitian ini dilakukan secara langsung, sebab data yang diolah berasal dari jawaban kuesioner oleh responden. Proses pembuatan kuesioner yaitu merujuk pada faktor-faktor yang ada pada Technology Acceptance Model (TAM). Sedangkan untuk menentukan populasi responden pada penelitian ini, penulis menggunakan metode Taro Yamane [9]. Adapun penetuan populasi dari responden yaitu merujuk pada hasil kunjungan dan data pasien yang telah terdaftar pada sistem informasi website RS Padma Lalita jumlahnya sekitar 200 orang. Rumus perhitungan jumlah responden yang akan digunakan bisa dilihat pada persamaan 1 [9]:

( $\mathrm{n}=$ Ukuran sampel)

$$
n=\frac{\mathrm{N}}{\mathrm{N} \cdot d^{2}+1}(1)
$$

( $\mathrm{N}=$ Ukuran populasi)

$(\mathrm{d}=$ Presisi, ditetapkan sebesar $10 \%$ dengan tingkat kepercayaan sebesar

$95 \%$ dari 200 jumlah populasi yang ada)

$$
\begin{aligned}
& =\frac{200}{\left(200 \times\left(0,1^{2}\right)+1\right)} \\
& =\frac{200}{(200 \times 0,01)+1} \\
& =66.66666667
\end{aligned}
$$

Berdasarkan rumus pengambilan sampel di atas maka besaran sampel berdasarkan populasi dari penelitian ini adalah sebesar 66 sampel/responden. Uji validitas dilakukan untuk melihat butir-butir pertanyaan mana yang layak (representative) digunakan untuk mewakili variabel penelitian. Selain harus valid, instrument juga harus reliable (dapat diandalkan). Uji reliabilitas dimaksudkan untuk mengukur tingkat konsistensi instrumen yang digunakan. Dalam penelitian ini analisis yang digunakan adalah analisis univariat (analisis deskriptif).

\subsection{Metode Analisis Data}

Analisis data yang digunakan dengan bentuk deskriptif yang dilakukan dengan bantuan software SPSS untuk memperoleh hasil rata-rata serta persentase. Analisis statistik deskriptif adalah analisis dengan cara mengubah data mentah menjadi bentuk yang lebih mudah dipahami dan diinterpretasikan. Analisis ini memberi gambaran atau deskriptif suatu data. Untuk analisis pengumpulan data yaitu melalui proses pembuatan kuesioner yaitu dengan merujuk pada faktorfaktor yang ada pada Technology Acceptance Model (TAM). Tahap selanjutnya yaitu dengan 
mengelola data yang sudah diperoleh menggunakan teknik analisis deskriptif dan teknik analisis regresi linier berganda.

Tipe pengukuran data yang digunakan adalah skala likert yaitu untuk mengukur sikap, pendapat dan persepsi seseorang atau sekelompok tentang kejadian. Adapun skala yang digunakan yaitu lima skala likert dengan ketentuan: Sangat Setuju (SS), Setuju (S), Netral (N), Tidak Setuju (TS), Sangat Tidak Setuju (STS) [10].

\subsection{Alur Penelitian}

Alur penelitian yang akan dilakukan dari awal sampai akhir penelitian akan dipaparkan pada Gambar 1.

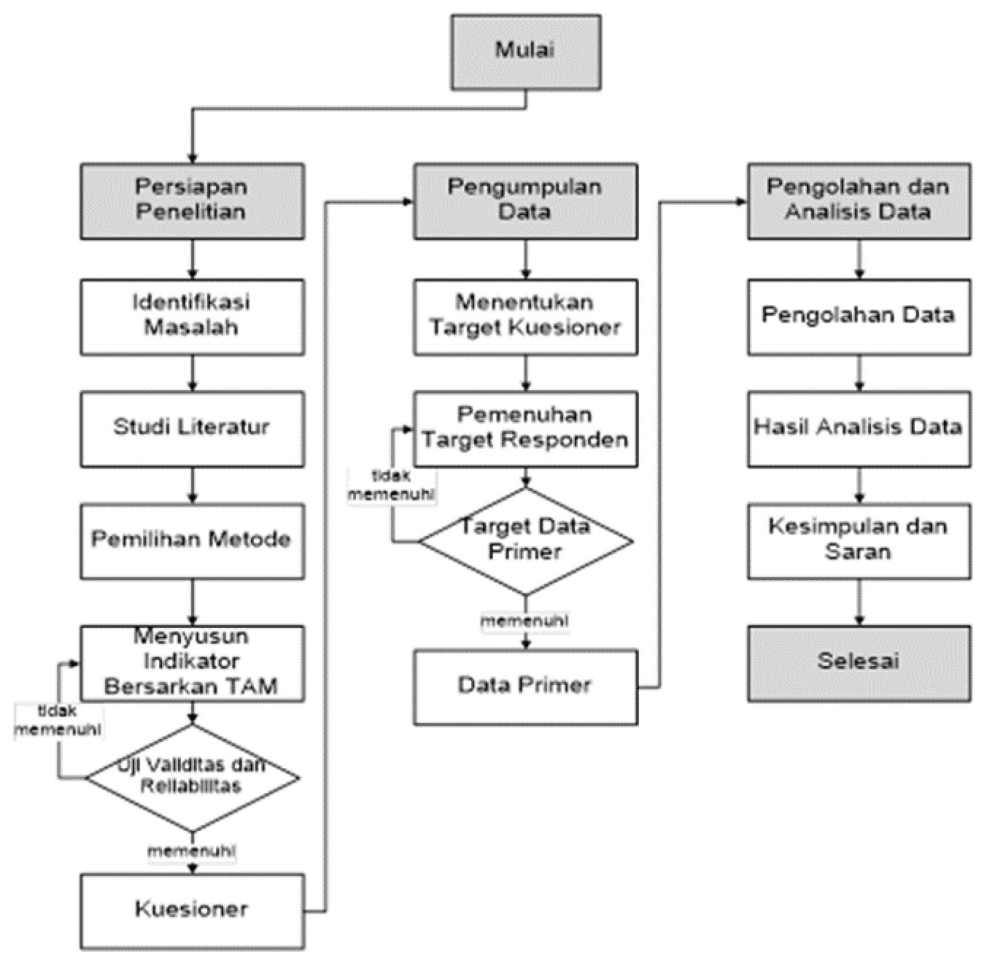

Gambar 1. Alur Penelitian

Pertama dilakukan perumusan masalah dari penelitian yang akan dilakukan, selanjutnya dilakukan tinjauan pustaka dengan cara studi pustaka/jurnal yang hampir sama dengan penelitian yang dilakukan. Selanjutnya adalah pengumpulan data dengan cara wawancara terhadap sumber yang bersangkutan dan melakukan penyebaran kuisioner kepada responden yang telah ditentukan. Langkah berikutnya adalah melakukan olah data dengan metode regresi linier berganda dengan langkah yang dilakukan di dalamnya adalah uji validitas dan realibilitas serta pengujian hipotesis.

\section{HASIL DAN PEMBAHASAN}

Pada bagian ini akan dibahas hasil uji instrumen penelitian, hasil uji prasyarat analisis, estimasi model regresi dan hasil pengujian hipotesis. Hasil uji instrumen penelitian terdiri atas hasil uji validitas butir instrumen dan hasil uji reliabilitas instrumen, hasil uji prasyarat analisis meliputi hasil uji normalitas residu, hasil uji heteroskedastisitas. Hasil estimasi model regresi melaporkan hasil analisis dua model persamaan regresi yang diajukan. Yang terakhir adalah hasil pengujian hipotesis melaporkan hasil pengujian hipotesis yang diajukan pada penelitian ini. 


\subsection{Hasil Uji Instrumen Penelitian}

Hasil pengujian instrumen penelitian mencakup hasil pengujian validitas instrumen dan hasil pengujian reliabilitas instrumen, seperti yang dilaporkan berikut.

\subsubsection{Hasil Uji Validitas Butir}

Uji validitas atau kesahihan digunakan untuk mengetahui seberapa tepat suatu alat ukur mampu melakukan fungsinya. Alat ukur yang dapat digunakan dalam pengujian suatu kuesioner adalah angka hasil korelasi antara skor pernyataan (skor butir) dan skor keseluruhan (skor total) pernyataan responden terhadap informasi dalam kuesioner [11]. Instrumen terlebih dahulu dinilai oleh ahli di bidangnya (expert judgment) untuk mengetahui validitas internal (validitas konstruk dan isi) dari instrumen yang bersangkutan, yaitu apakah instrumen yang akan digunakan telah betul-betul mencakup konstruk dan aspek dari variabel yang bersangkutan. Lalu instrumen itu diperiksa validitas eksternalnya dengan melakukan uji coba setidaknya dengan 30 responden.

Pengujian validitas eksternal menggunakan angka $r$ hasil korelasi Pearson yang dikenal dengan rumus korelasi Product Moment [12]. Dalam estimasi validitas pada umumnya tidak dapat dituntut suatu koefisien yang tinggi sekali. Koefisien validitas yang tidak begitu tinggi berada di sekitar angka 0,50 akan dapat diterima dan dianggap memuaskan. Namun apabila koefisien validitas itu kurang dari pada 0,30 biasanya dianggap tidak memuaskan [12].

Dalam penelitian ini, ada tiga instrumen yang akan divalidasi sebelum digunakan untuk mengumpulkan data di lapangan yaitu instrumen Attitude Toward Using (AT, sebagai Y), Perceived Usefulness (PU, sebagai X1), dan Perceived Ease of Use (PE, sebagai X2). Perhitungan validitas instrumen yang berupa angket dengan pendekatan internal konsistensi, menggunakan bantuan program SPSS. Berdasarkan hasil perhitungan apabila nilai corrected item-total correlation tersebut $\geq 0,30$ maka butir pernyataan dalam angket dinyatakan valid atau sahih [12]. Hasil uji instrumen dengan metode corrected item-total correlation dilaporkan berikut ini.

a. Instrumen Attitude toward Using

Variabel Attitude Toward Using diukur dengan menggunakan instrumen yang terdiri atas 6 butir pertanyaan. Hasil pengujian validitas butir disajikan pada Tabel 1 .

Tabel 1. Hasil Uji Validitas Butir Instrumen Attitude Toward Using

\begin{tabular}{|c|c|c|c|}
\hline Butir & Korelasi Butir-Total & Syarat Minimal & Keterangan \\
\hline AT1 & 0,360 & 0,300 & Valid \\
\hline AT2 & 0,590 & 0,300 & Valid \\
\hline AT3 & 0,598 & 0,300 & Valid \\
\hline AT4 & 0,521 & 0,300 & Valid \\
\hline AT5 & 0,679 & 0,300 & Valid \\
\hline AT6 & 0,767 & 0,300 & Valid \\
\hline
\end{tabular}

Tabel 1 menunjukkan koefisien korelasi yang berkisar dari 0,360 (butir AT1) sampai dengan 0,767 (AT6). Karena koefisien korelasi item-total lebih besar dari 0,300 maka dapat disimpulkan bahwa semua item adalah valid (sahih).

b. Instrumen Perceived Usefulness

Variabel Perceived Usefulness diukur dengan instrumen yang terdiri atas 6 item pernyataan yaitu PU1 sampai dengan PU6. Hasil uji validitas butir instrumen disajikan pada Tabel 2. 
Tabel 2. Hasil Uji Validitas Butir Instrumen Perceiced Usefulness

\begin{tabular}{|l|r|r|c|}
\hline Butir & Korelasi Butir-Total & Syarat Minimal & Keterangan \\
\hline PU1 & 0,490 & 0,300 & Valid \\
\hline PU2 & 0,499 & 0,300 & Valid \\
\hline PU3 & 0,541 & 0,300 & Valid \\
\hline PU4 & 0,377 & 0,300 & Valid \\
\hline PU5 & 0,650 & 0,300 & Valid \\
\hline PU6 & 0,701 & 0,300 & Valid \\
\hline
\end{tabular}

Tabel 2 menunjukkan koefisien korelasi yang berkisar dari 0,377 (butir PU4) sampai dengan 0,701 (PU6). Karena koefisien korelasi item-total lebih besar dari 0,300 maka dapat disimpulkan bahwa semua item instrumen perceived usefulnes adalah valid (sahih).

c. Instrumen Perceived Ease of Use

Variabel Perceived Ease of Use diukur dengan menggunakan instrumen yang terdiri atas 6 butir (item) pernyataan. Hasil uji validitas butir disajikan pada Tabel 3.

Tabel 3. Hasil Uji Validitas Butir Instrumen Perceiced Ease of Use

\begin{tabular}{|c|r|r|c|}
\hline Butir & Korelasi Butir-Total & Syarat Minimal & Keterangan \\
\hline PE1 & 0,411 & 0,300 & Valid \\
\hline PE2 & 0,436 & 0,300 & Valid \\
\hline PE3 & 0,364 & 0,300 & Valid \\
\hline PE4 & 0,532 & 0,300 & Valid \\
\hline PE5 & 0,602 & 0,300 & Valid \\
\hline PE6 & 0,512 & 0,300 & Valid \\
\hline
\end{tabular}

Tabel 3 menunjukkan koefisien korelasi item-total yang berkisar dari 0,364 (PE3) sampai dengan 0,602 (PE5). Karena koefisien korelasi item-total lebih besar dari 0,300 maka dapat disimpulkan bahwa semua item instrumen perceived ease of use adalah valid (sahih).

\subsubsection{Hasil Uji Reliabilitas Instrumen}

Tujuan utama pengujian reliabilitas instrumen adalah untuk mengetahui konsistensi atau keteraturan hasil pengukuran suatu instrumen apabila instrumen tersebut digunakan lagi sebagai alat ukur suatu objek atau responden [11]. Salah satu metode pengujian reliabilitas adalah dengan menggunakan metode Alpha-Cronbach [12]:

Perhitungan reliabilitas instrumen dapat dilakukan dengan menggunakan formula Alpha Cronbach. Suatu instrumen dikatakan reliabel (andal) bila memiliki koefisien Alpha Cronbach $\geq$ 0,70. Hasil uji reliabilitas menggunakan metode Alpha Cronbach dirangkum dalam Tabel 4.

Tabel 4. Rangkuman Hasil Uji Reliabilitas Instrumen

\begin{tabular}{|l|c|c|c|}
\hline \multicolumn{1}{|c|}{ Instrumen } & Alpha Cronbach & Syarat Minimal & Keterangan \\
\hline Perceived Usefulness & 0,766 & 0,70 & Reliabel/Andal \\
\hline Perceived Ease of Use & 0,789 & 0,70 & Reliabel/Andal \\
\hline Attitude toward Using & 0,891 & 0,70 & Reliabel/Andal \\
\hline
\end{tabular}

Tabel 4 menunjukkan ketiga instrumen penelitian memiliki tingkat reliabilitas yang tinggi dan memenuhi syarat untuk digunakan mendapatkan data penelitian di lapangan. Ketiga instrumen tersebut memiliki koefisien Alpha Cronbach $>0,70$. 


\subsection{Hasil Analisis Deskriptif}

Analisis deskriptif bertujuan untuk menggambarkan masing-masing variabel yang diteliti, yaitu Perceived Usefulness, Perceived Ease of Use dan Attitude toward Using. Analisis deskriptif pada penelitian ini mencakup penyajian mean (nilai rerata) dan juga kategorisasi data ke dalam kategori sangat rendah, rendah, sedang, tinggi, dan sangat tinggi untuk tiap variabel.

Untuk mendeskripsikan variabel penelitian, nilai rata-rata masing-masing responden pada masing-masing variabel dikelompokkan dalam 5 kelas. Cara mengetahui kecenderungan responden maka dibuat pengelompokan berdasarkan norma yang disusun sesuai dengan tingkat diferensiasi yang dikehendaki dan ditetapkan batasannya berdasarkan rentang skor minimummaksimum teoritiknya.

Norma kategorisasi atau klasifikasi yang digunakan dapat dilihat pada Tabel 5 [13]:

Tabel 5. Norma Kategorisasi

\begin{tabular}{|l|l|c|c|}
\hline Sangat rendah & $\mathrm{Mt}-1,5 \mathrm{SDt}$ & $\geq \mathrm{X}$ & \\
\hline Rendah & $\mathrm{Mt}-0,5 \mathrm{SDt}$ & $\geq \mathrm{X}>$ & $\mathrm{Mt}-1,5 \mathrm{SDt}$ \\
\hline Sedang & $\mathrm{Mt}+0,5 \mathrm{SDt}$ & $\geq \mathrm{X}>$ & $\mathrm{Mt}-0,5 \mathrm{SDt}$ \\
\hline Tinggi & $\mathrm{Mt}+1,5 \mathrm{SDt}$ & $\geq \mathrm{X}>$ & $\mathrm{Mt}+0,5 \mathrm{SDt}$ \\
\hline Sangat tinggi & & $\mathrm{X}>$ & $\mathrm{Mt}+1,5 \mathrm{SDt}$ \\
\hline
\end{tabular}

Mt adalah Mean atau rata-rata teoritik, diperoleh dari penjumlah skor maksimum teoritik dan skor minimum teoritik, lalu dibagi dua atau $\mathrm{Mt}=($ Skor Maksimum + Skor Minimum $) / 2$. Sedangkan SDt adalah standar deviasi teoritik yang diperoleh dari skor maksimum teoritik dikurangi skor minimum teoritik dan dibagi enam atau SDt $=$ (Skor Maksimum - Skor Minimum) $/ 6$ [13].

Instrumen keempat variabel dalam penelitian ini diukur dengan skala 5 poin yang memiliki rentang pilihan jawaban 1 hingga 5 , jadi skor tertinggi atau maksimum $=5$ dan skor terendah atau minimum $=1$. Mean teoritik $(\mathrm{Mt})$ diperoleh sebesar $(5+1) / 2=3$ dan standar deviasi teoritik (SDt) sebesar 1/6 x $(5-1)=0,67$. Berdasarkan mean teoritlk dan standar devasi teoritik ini, maka dapat ditentukan klasifikasi dengan 5 kategori seperti yang terlihat pada Tabel 6.

Tabel 6. Klasifikasi Berdasarkan Norma Kategorisasi

\begin{tabular}{|l|c|c|c|}
\hline Sangat rendah & $3-(1,5 \times 0,67)$ & $\geq X$ & \\
\hline Rendah & $3-(0,5 \times 0,67)$ & $\geq X>$ & $3-(1,5 \times 0,67)$ \\
\hline Sedang & $3+(0,5 \times 0,67)$ & $\geq X>$ & $3-(0,5 \times 0,67)$ \\
\hline Tinggi & $3+(1,5 \times 0,67)$ & $\geq X>$ & $3+(0,5 \times 0,67)$ \\
\hline Sangat tinggi & & $X>$ & $3+(1,5 \times 0,67)$ \\
\hline
\end{tabular}

Tabel 7. Klasifikasi Nilai Instrumen

\begin{tabular}{|l|c|c|c|}
\hline Sangat rendah & 2,00 & $\geq X$ & \\
\hline Rendah & 2,67 & $\geq X>$ & 2,00 \\
\hline Sedang & 3,33 & $\geq X>$ & 2,67 \\
\hline Tinggi & 4,00 & $\geq X>$ & 3,33 \\
\hline Sangat tinggi & & $X>$ & 4,00 \\
\hline
\end{tabular}

Berdasarkan klasifikasi pada Tabel 6 dan Tabel 7, dapat dilakukan proses pengelompokan data variabel penelitian dan mean empirik hasil pengukuran di lapangan dan menghitung banyak responden yang termasuk dalam tiap kelompok yang telah ditetapkan. 
1. Perceived Usefulness

Mean dari variabel perceived usefulness sebesar 3,94 yang masuk ke dalam kategori "tinggi", dengan simpangan baku sebesar 0,515. Dengan menggunakan kaidah kategori seperti yang disajikan pada Tabel 8 [13].

Tabel 8. Kategorisasi Variabel Perceived Usefulness

\begin{tabular}{|r|r|r|r|r|}
\hline & Frequency & Percent & Percent Valid & Comulative Percent \\
\hline Sedang & 7 & 10.0 & 10.0 & 10.0 \\
Tinggi & 32 & 48.5 & 48.5 & 59.6 \\
Sangat Tinggi & 27 & 41.5 & 41.5 & 100.0 \\
Total & 66 & 100.0 & 100.0 & \\
\hline
\end{tabular}

Tabel 8 menunjukkan bahwa $32(48,5 \%)$ responden memberikan penilaian tinggi terhadap kegunaan yang dirasakan (perceived usefulness), disusul 27 (41,5\%) memberikan penilaian "sangat tinggi" terhadap kegunaan yang dirasakan.

2. Perceived Ease of Use

Mean dari variabel perceived ease of use sebesar 4,04 yang masuk ke dalam kategori "sangat tinggi", dengan simpangan baku sebesar 0,460. Dengan menggunakan kaidah kategori seperti yang disajikan pada Tabel 9 [13].

Tabel 9. Kategorisasi Variabel Perceived Ease of Use

\begin{tabular}{|r|r|r|r|r|}
\hline & Frequency & Percent & Percent Valid & Comulative Percent \\
\hline Rendah & 1 & 1.0 & 1.0 & 1.0 \\
Sedang & 10 & 15.2 & 15.2 & 16.2 \\
Tinggi & 29 & 44.5 & 46.5 & 62.6 \\
Sangat Tinggi & 26 & 39.4 & 37.4 & 100.0 \\
Total & 66 & 100.0 & 100.0 & \\
\hline
\end{tabular}

Tabel 9. menunjukkan bahwa $29(44,5 \%)$ responden memberikan penilaian tinggi terhadap kemudahan yang dirasakan (perceived ease of use), disusul $26(39,4 \%)$ memberikan penilaian "sangat tinggi" terhadap kemudahan yang dirasakan.

3. Attitude toward Using

Mean dari variabel attitude toward using sebesar 3,75 yang masuk ke dalam kategori "tinggi", dengan simpangan baku sebesar 0,619. Tabel 10 menunjukkan bahwa 29 (43,5\%) responden memberikan penilaian tinggi terhadap attutide toward using, disusul 25 (40,4\%) memberikan penilaian "sangat tinggi" terhadap attitude toward using.

Tabel 10. Kategorisasi Variabel Attitude Toward Using

\begin{tabular}{|r|r|r|r|r|}
\hline & Frequency & Percent & Percent Valid & Comulative Percent \\
\hline Sangat Rendah & 1 & 1.0 & 1.0 & 1.0 \\
Rendah & 2 & 2.0 & 2.0 & 3.0 \\
Sedang & 9 & 16.2 & 16.2 & 28.2 \\
Tinggi & 29 & 43.5 & 43.5 & 71.6 \\
Sangat Tinggi & 25 & 40.4 & 40.4 & 100.0 \\
Total & 66 & 100.0 & 100.0 & \\
\hline
\end{tabular}

Tabel 10 menunjukkan bahwa $29(43,5 \%)$ responden memberikan penilaian tinggi terhadap attutide toward using, disusul $25(40,4 \%)$ memberikan penilaian "sangat tinggi" terhadap attitude toward using. 


\subsection{Hasil Uji Prasyarat Analisis}

Sebelum dilakukan analisis regresi linier berganda, terlebih dahulu dilakukan uji prasyarat analisis. Uji prasyarat analisis digunakan untuk mengetahui dan menguji kelayakan dari analisis regresi pada penelitian ini, yang meliputi uji normalitas residu, uji multikolinieritas dan uji heteroskedastisitas.

\subsubsection{Hasil Uji Normalitas Residu}

Imam Ghozali, 2013, menyebutkan bahwa uji normalitas bertujuan untuk menguji apakah dalam model regresi, variabel penganggu atau residual memiliki distribusi normal. Jika residu memiliki distribusi normal, model regresi akan mampu memberikan prediksi yang lebih akurat. Pada penelitian ini, uji normalitas residu dilakukan dengan menggunakan uji statistik nonparametrik Kolmogrov-Smirnov (K-S) untuk menguji normalitas residualnya. Dasar pengambilan keputusan uji statistik dengan Kolmogorov-Smirnov Z (1-Sample K-S) adalah [14]:

a. Jika nilai Asymp. Sig. (2-tailed) kurang dari 0,05, maka H0 ditolak. Hal ini berarti data residual terdistribusi tidak normal.

b. Jika nilai Asymp. Sig. (2-tailed) lebih dari 0,05, maka H0 diterima. Hal ini berarti data residual terdistribusi normal.

Gambar 2 merupakan hasil dari pengujian normalitas dengan uji Kolmogorov-Smirnov Z (1-Sample K-S) yang menyajikan nilai Z Kolmogorov-Smirnov dan nilai signifikansi p.

\begin{tabular}{|ll|r|}
\hline & & \multicolumn{1}{|c|}{$\begin{array}{c}\text { Unstandardized } \\
\text { Residual }\end{array}$} \\
\hline N & & 66 \\
Normal Parameters a.b & Mean &, 000000 \\
Most Extreme & Std. Deviation &, 3994817 \\
Differences & Absolute &, 116 \\
& Positive &, 089 \\
Kolmogorov-Smirnov Z & Negative & -116 \\
Asymp. Sig. (2-tailed) & & 1,155 \\
\hline
\end{tabular}

a. Test distribution is Normal.

b. Calculated from data.

Gambar 2. Hasil Pengujian Normalitas Residu

\subsubsection{Hasil Uji Multikolinieritas}

Imam Ghozali, menyebutkan bahwa uji multikolonieritas bertujuan untuk menguji apakah dalam model regresi ditemukan adanya korelasi yang terlalu tinggi antar variabel bebas (independen). Model regresi yang baik seharusnya tidak terjadi korelasi yang terlalu tinggi $(>0,9)$ di antara variabel independen. Untuk mendeteksi ada tidaknya multikolonieritas, dapat dilihat dari nilai tolerance dan lawannya variance inflation factor (VIF). Kedua ukuran ini menunjukkan setiap variabel independen manakah yang dijelaskan oleh variabel independen lainnya. Tolerance mengukur variabilitas variabel independen yang terpilih yang tidak dijelaskan oleh variabel independen lainnya. Jadi nilai tolerance yang rendah sama dengan nilai VIF tinggi (karena VIF= $1 /$ Tolerance). Nilai cut off yang umum dipakai untuk menunjukkan adanya multikolonieritas adalah nilai tolerance $>0.10$ atau sama dengan nilai VIF $<10$ [14]. Hasil uji multikolinieritas dengan menggunakan nilai VIF dan Tolerance disajikan pada Gambar 3. 


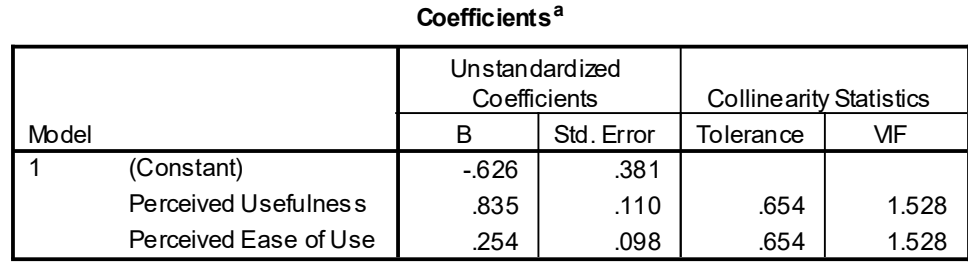

a. Dependent Variable: Attitude toward Using

Gambar 3. Hasil Uji Multikolinieritas

Gambar 3 menunjukkan bahwa nilai tolerance untuk variabel perceived usefulness dan perceived ease of use berturut-turut adalah 0,654 dan 0,654 Karena nilai-nilai ini berada di atas nilai cut off 0,10 maka dapat disimpulkan bahwa model regresi tidak mengandung problem moltikolinieritas. Demikian juga, halnya jika ditinjau dari nilai VIF dari variabel bebas berturutturut sebesar 1,528, dan 1,528 yang berada di bawah nilai cut-off sebesar 10,00. Karena nilai VIF berada di bawah 10,0 maka dapat disimpulkan bahwa model regresi tidak mengandung problem moltikolinieritas.

\subsubsection{Hasil uji Heteroskedastisitas}

Ghozali menyebutkan bahwa uji heterokedasitas bertujuan untuk menguji apakah dalam model regresi terjadi ketidaksamaan variance dari residual satu pengamatan ke pengamatan yang lain. Jika variance dari residual satu pengamatan ke pengamatan lain tetap (atau mendekati sama) maka disebut model berada pada kondisi homoskedastisitas dan jika berbeda disebut heteroskedastisitas. Model regresi yang baik adalah model yang tidak memiliki problem heterokedasitisitas [14], sehingga variance dari residual satu pengamatan ke pengamatan yang lain mendekati sama. Dalam penelitian ini, digunakan uji Glejser dalam menguji ada tidaknya heteroskedastisitas.

Uji Glejser dilakukan dengan meregresi variabel nilai absout residu (AbsUt) terhadap semua variabel independen dalam model. Pengukuran variabel dikatakan terbebas dari heteroskedastisitas dapat dilihat dari probabilitas signifikansinya, bila tingkat signifikannya berada di atas $5 \%$ maka dapat disimpulkan model regresi tersebut tidak mengandung problem heterokedastisitas. Artinya, variabel-variabel independen tidak memiliki pengaruh nyata terhadap nilai absolut dari residu (AbsUt). Gambar 4 menunjukkan hasil dari pengujian heteroskedastisitas.

\begin{tabular}{|c|c|c|c|c|c|c|}
\hline \multirow[b]{2}{*}{ Mode } & & \multicolumn{2}{|c|}{$\begin{array}{l}\text { Unstandardized } \\
\text { Coefficients }\end{array}$} & \multirow{2}{*}{$\begin{array}{c}\begin{array}{c}\text { Standardized } \\
\text { Coefficients }\end{array} \\
\text { Beta }\end{array}$} & \multirow[b]{2}{*}{$t$} & \multirow[b]{2}{*}{ Sig. } \\
\hline & & B & Std. Error & & & \\
\hline \multirow[t]{3}{*}{1} & (Constant) & .527 & .250 & & 2.109 & .038 \\
\hline & Perceived Usefulness & -.032 & .072 & -.055 & -.442 & .660 \\
\hline & Perœived Ease of Use & -.025 & .064 & -.050 & -.396 & .693 \\
\hline
\end{tabular}

a. Dependent Variable: Absolut Residu

Gambar 4. Hasil Uji Multikolinieritas

Sumber: Hasil pengolahan data primer (2018)

Gambar 4 menunjukkan bahwa nilai signifikansi $\mathrm{p}$ untuk variabel perceived usefulness dan perceived ease of use berturut-turut adalah 0,660 dan 0,693. Nilai signifikansi tersebut terbukti lebih besar dari 0,05 sehingga dapat disimpulkan bahwa model regresi yang diteliti tidak mengandung problem heteroskedastisitas. 
Citec Journal, Vol. 5, No. 3, Mei 2018 - Juli 2018

ISSN: 2460-4259

\subsection{Estimasi Model Regresi}

Estimasi model regresi yang dapat dinyatakan dalam bentuk persamaan regresi linier berganda seperti pada persamaan 2 :

Keterangan:

$$
\mathrm{Y}=\mathrm{a}_{1}+\mathrm{b}_{1} \mathrm{X}_{1}+\mathrm{b}_{2} \mathrm{X}_{2}+\mathrm{e}
$$

$\begin{array}{lll}\mathrm{Y} & : & \text { Attitude toward using } \\ \mathrm{X}_{1} & : & \text { Perceived usefulness } \\ \mathrm{X}_{2} & : & \text { Perceived ease of use } \\ \mathrm{A} & : & \text { Konstanta regresi } \\ \mathrm{b}_{1}, \mathrm{~b}_{2} & : & \text { Koefisien regresi } \\ \mathrm{E} & : & \text { Residu atau error terms }\end{array}$

\subsubsection{Persamaan Regresi}

Persamaan regresi linier berganda pada penelitian ini dapat dihasilkan dengan memasukkan nilai konstanta dan koefisien regresi ke dalam Persamaan. Nilai konstanta dan koefisien regresi dapat dilihat dari hasil keluaran SPSS untuk koefisien persamaan regresi yang disajikan pada Gambar 5.

Coefficients $^{a}$

\begin{tabular}{|ll|r|r|r|r|r|}
\hline \multirow{2}{*}{ Mbdel } & \multicolumn{2}{|c|}{$\begin{array}{c}\text { Unstandardized } \\
\text { Coefficients }\end{array}$} & $\begin{array}{c}\text { Standardized } \\
\text { Coefficients }\end{array}$ & & \multirow{2}{*}{ Sig. } \\
\cline { 3 - 5 } & & \multicolumn{1}{|c|}{ B } & Std. Error & \multicolumn{1}{c|}{ Beta } & \multicolumn{1}{c|}{$\mathrm{t}$} & .104 \\
& (Constant) & -.626 & .381 & & -1.641 & .600 \\
& Perceived Usefulness & .835 & .110 & .621 & 7.627 & .011 \\
\hline
\end{tabular}

a. Dependent Variable: Attitude tow ard Using

Gambar 5. Konstanta Dan Koefisien Regresi

\subsubsection{Koefisien Determinasi (R2)}

Koefisien determinasi $\left(\mathrm{R}^{2}\right)$ pada intinya mengukur seberapa jauh kemampuan model dalam menerangkan variasi variabel dependen. Nilai $\mathrm{R}^{2}$ berada di antara nol dan satu. Nilai $\mathrm{R}^{2}$ yang kecil berarti kemampuan variabel-variabel independen dalam menjelaskan variabel dependen sangat terbatas. Nilai yang mendekati satu berarti variabel-variabel independen memberikan hampir semua informasi yang dibutuhkan untuk memprediksi variasi variabel independen [14].

Keluaran (output) SPSS untuk nilai $\mathrm{R}^{2}$ menunjukkan nilai sebesar 0,584. Angka ini menunjukkan bahwa 0,584 atau 58,4\% variasi atau perubahan pada variabel dependen Attitude toward Using dapat dijelaskan oleh variabel independen $\mathrm{X}_{1}$ (Perceived Usefulness) dan $\mathrm{X}_{2}$ (Perceived Ease of Use), sedangkan 37,8\% sisanya dipengaruhi oleh variabel lain di luar model regresi yang digunakan.

\subsubsection{Pengujian Hipotesis}

Hasil pengujian hipotesis berdasarkan nilai signifikansi p dapat dilihat pada Tabel 15.

Tabel 15. Rangkuman Hasil Pengujian Hipotesis

Sumber: Hasil pengolahan data primer (2018)

\begin{tabular}{|l|c|c|c|}
\hline Variabel & t hitung & Signifikansi $\mathrm{p}$ & Pengaruh \\
\hline Perceived Usefulness $\left(\mathrm{X}_{1}\right)$ & 6,551 & 0,000 & Signifikan \\
\hline Perceived Ease of Use $\left(\mathrm{X}_{2}\right)$ & 1,988 & 0,011 & Signifikan \\
\hline Variabel dependen: $\mathrm{Y}($ Attitude toward using) \\
Nilai statistik F hitung $=25,378$ (signifikansi $\mathrm{p}=0,000)$ \\
\hline
\end{tabular}


Kriteria pengujian hipotesis yang digunakan adalah jika nilai signifikansi sp untuk nilai $\mathrm{t}$ statistik $>0,05$, maka hipotesis ditolak. Sementara itu, pengujian pengaruh simultan kedua variabel $\mathrm{X} 1$ dan $\mathrm{X} 2$ terhadap $\mathrm{Y}$ (Attitude toward using) dilakukan dengan melihat nilai signifikansi $\mathrm{p}$ dari nilai $\mathrm{F}$ statistik, yaitu jika nilai $\mathrm{p}>0,05$ maka hipotesis ditolak. Hasil pengujian hipotesis dirangkum sebagai berikut:

H1 Perceived Usefulness Sistem Informasi Rumah Sakit Padma Lalita Magelang memiliki pengaruh signifikan terhadap Attitude toward Using diterima karena thitung $=6,551$ dengan signifikansi $\mathrm{p}=0,000(<0,05)$.

$\mathrm{H} 2 \quad$ Perceived Ease of Use Sistem Informasi Rumah Sakit Padma Lalita Magelang memiliki pengaruh signifikan terhadap Attitude toward Using diterima karena thitung $=1,988$ dengan signifikansi $\mathrm{p}=0,011(<0,05)$

H3 Perceived Usefulness dan Perceived Ease of Use Sistem Informasi Rumah Sakit Padma Lalita Magelang secara bersama-sama (simultan) memiliki pengaruh signifikan terhadap Attitude toward Using diterima karena nilai statistik F hitung $=59,712$ dengan signifikansi $\mathrm{p}=0,000(<0,05)$.

\section{KESIMPULAN}

Berdasarkan hasil penelitian tentang Analisis Penerimaan Sistem Informasi Rumah Sakit Padma Lalita Magelang, selanjutnya dapat ditarik beberapa kesimpulan berikut ini:

1. Perceived usefulness, perceived ease of use, dan attitude toward using berturut-turut masuk ke dalam kategori "sangat tinggi", "tinggi", dan "tinggi". Ini menunjukkan bahwa Sistem Informasi Rumah Sakit Padma Lalita Magelang dinilai baik oleh para pengguna sistem. Perceived usefulness memiliki pengaruh signifikan terhadap variabel dependen attitude toward using, jadi ketika kegunaan yang dirasakan mengalami peningkatan, maka sikap terhadap penggunaan akan mengalami peningkatan secara positif. Perceived ease of use memiliki pengaruh signifikan terhadap variabel dependen attitude toward using, jadi ketika sistem dirasakan semakin mudah oleh pengguna, maka sikap terhadap penggunaan akan mengalami peningkatan secara positif. Secara bersama-sama, perceived usefulness dan perceived ease of use memiliki pengaruh yang signifikan terhadap attitude toward using. Artinya variabel perceived usefulness dan perceived ease of use bersinergi memberikan pengaruh simultan terhadap attitude toward using.

2. Rekomendasi untuk perbaikan atau peningkatan sistem adalah yang pertama dari segi jangkauan dan kegunaan disarankan untuk membuat aplikasi android agar akses menuju sistem lebih mudah. Kemudian yang kedua adalah mengganti ukuran dan jenis huruf supaya lebih terlihat dengan jelas atau mudah dibaca, serta penambahan petunjuk tata cara pendaftaran pasien. Yang ketiga adalah memperbaharui artikel dan berita pada halaman berita supaya user mendapatkan informasi lebih mengenai pelayanan kesehatan.

\section{SARAN}

Saran yang dapat diberikan terhadap penelitian tentang Analisis Penerimaan Sistem Informasi Rumah Sakit Padma Lalita Magelang, adalah sebagai berikut:

1. Pengembangan platform baru untuk sistem informasi yang sekarang selain menggunakan website. Disarankan membuat platform lain seperti android.

2. Terdapat residu $37,8 \%$ yang tidak dapat dijelaskan variabel independen yang diteliti. Jadi disarankan untuk meneliti variabel lain yang berpengaruh terhadap attitude toward using. 


\section{DAFTAR PUSTAKA}

[1] Davis, F. D., 1989, Perceived Usefulness, Perceived Ease of Use, and User Acceptance of Information Technology, MIS Quaterly, No. 3, Vol. 13, Hal. 319-340.

[2] Järvinen, J., Ohtonen, R.,Karjaluoto, H., 2016, Consumer Acceptance and Use of Instagram, Hawaii International Conference on System Sciences (HICSS), Koloa, USA, January 5-8.

[3] Megawati., Firnandi, R., 2017, Analisis Perbandingan Metode Tam dan Utaut Dalam Mengevaluasi Penerimaan Pengguna Sistem Informasi Manajemen Rumah Sakit (SIMRS), SNTIKI 9, Pekanbaru.

[4] Wingdes, I., 2016, Penerimaan Tekonologi Web Check-In pada Pengguna Transportasi Udara di Kalimantan Barat, CITEC Journal, Yogyakarta, No. 1, Vol. 3, Hal. 37-49.

[5] Sugiarto, S., Lianto, L., 2011, Analisis Penerapan Sistem Akuntansi Persediaan Menggunakan Technology Acceptance Model (TAM) pada Distrik Navigasi Kelas III Pontianak, Jurnal Ilmiah SISFOTENIKA, Pontianak, No. 2, Vol. 1, Hal. 80-94.

[6] Rozanda, E. R., Marsiana, A., 2017, Perbandingan Metode Hot Fit dan Tam dalam Mengevaluasi Penerapan Sistem Informasi, Seminar Nasional Teknologi Informasi, SNTIKI 9, Pekanbaru

[7] Mulik, S., Yajnik, N., Godse, M., 2016, Determinants of Acceptance of Massive Open Online Courses, IEEE International Conference on Technology for Education, Mumbai, India, December 2-4.

[8] Hasibuan, Z. A., 2007, Metodologi Penelitian Pada Bidang Ilmu Komputer dan Teknologi Informasi, Fakultas ILKOM UI, Jakarta.

[9] Rasyad, R., 2003, Metode Statistik Deskriptif, Grahasindo, Jakarta.

[10] Riduwan, 2007, Metode Penelitian Untuk Tesis, Alfabeta, Bandung.

[11] Triton, P. B., 2006, SPSS 13.0 Terapan: Riset Statistik Parametrik, Penerbit Andi Offset, Yogyakarta.

[12] Arikunto, S., 2010, Prosedur Penelitian: suatu Pendekatan Praktik, Rineka Cipta, Jakarta.

[13] Azwar, S., 2003, Penyusunan Skala Psikologi, Penerbit Pustaka Pelajar, Yogyakarta.

[14] Ghozali, I., 2013, Model Persamaan Struktural Konsep dan Aplikasi dengan Program Amos 21.0, Badan Penerbit Universitas Diponegoro, Semarang. 